Marquette University

e-Publications@Marquette

Library Faculty Research and Publications

Library (Raynor Memorial Libraries)

$1-1-2011$

Engaging Alumni and Prospective Students Through Social Media

Eric A. Kowalik

Marquette University, eric.kowalik@marquette.edu

Author version. Eric Kowalik, "Engaging Alumni and Prospective Students Through Social Media," in Higher Education Administration with Social Media. Eds. Laura A. Wankel and Charles Wankel. Emerald Group Publishing, Ltd. 2011: 211-227

This book chapter is (C) Emerald Group Publishing and permission has been granted for this version to appear on e-Publications@Marquette. Emerald does not grant permission for this article to be further copied/distributed or hosted elsewhere without the express permission from Emerald Group Publishing Limited. 
NOT THE PUBLISHED VERSION; this is the author's final, peer-reviewed manuscript. The published version may be accessed by following the link in the citation at the bottom of the page.

\title{
Engaging Alumni and Prospective Students Through Social Media
}

\author{
Eric Kowalik \\ Raynor and Memorial Libraries, Marquette University \\ Milwaukee, WI
}

\begin{abstract}
Social media provides institutions an opportunity for a new level of engagement with prospective students, alumni, donors and community members. This chapter begins with an overview of social media in higher education, who is using it and for what, then provides a few talking points to consider with others before beginning a push into social media. The remainder of the chapter includes a few examples of ways in which social media are used to engage alumni and prospective students, including utilizing Twitter as a free SMS service to provide updates to prospective students during their recruitment, creating an zPhone application for alumni weekend as both an information and engagement tool, and using live tweets from alumni during homecoming to provide an authentic look at the day's events.
\end{abstract}

The Web is changing the focus of modern advertising, which for many years was focused on drawing associations from the physical qualities of products to the unfulfilled yearnings of potential customers.

Erich Fromm (1969) compared modern advertising methods of influence to hypnosis:

All these methods are essentially irrational; they have nothing to do with the qualities of the merchandise, and they smother and kill the critical capacities of the customer like an opiate or outright hypnosis. (p. 128)

Higher Education Administration with Social Media: Including Applications in Student Affairs, Enrollment Management, Alumni Relations, and Career Centers, 2011: pg. 211-227. Publisher Link. This book chapter is @ Emerald Group Publishing, Ltd. and permission has been granted for this version to appear in e-Publications@Marquette. Emerald Group Publishing, Ltd. does not grant permission for this book chapter to be further copied/distributed or hosted elsewhere without the express permission from Emerald Group Publishing, Ltd. 
NOT THE PUBLISHED VERSION; this is the author's final, peer-reviewed manuscript. The published version may be accessed by following the link in the citation at the bottom of the page.

The value of emotion in web copy cannot be overemphasized, as Veloso (2009) states, "People buy on emotion and justify with logic. Emotion is such a powerful element of the online sales process; the most important objective of a salesperson, marketer, or copywriter is to deliver an emotional experience during the sales presentation" ( $p$. 161).

Despite the focus on traditional psychology in the advertising process, the web has created a new type of customer who is becoming immune to the hard sell of traditional marketing. If you need to sell it, it may not be worth buying. You do not need to sell the iPad. It sells itself, you just need to demo it to the customer. What the Web, blogs, and social media reflect is a customer revolt. The Web is a more rational space. The Web thrives in open, questioning cultures. The Web is not about technology, but psychology.

According to McGovern (2010a), a new type of customer is emerging. This customer is less emotional and more rational. This customer does not believe in blind faith. They are on the Web to research, compare, to find out for themselves. They wish to search out the views of others like them who have also bought the product rather than obediently accepting the organization's message.

If you want to be successful in engaging with this sort of customer then you need to think of them as an inquisitive stranger. Relentlessly focus on helping customers understand your product, service, and/or experience- not its advertisements. Marketing your institution should focus on engaging with the customer and showing them the desirable products, services, and/or experiences.

Sure, you can sell a brick. But when the good vibes are gone (and so are you) the buyer is left with ... a brick. That is not a sustainable longterm strategy. Social media provides you the opportunity to humanize stories of students and alumni of your institution, which can create loyalty and earn future business (students), and ultimately their respect (Solis, 2008).

The Conversation Prism graphic (Fig. 1), created by Brian Solis, provides a living, breathing representation of Social Media meant to

Higher Education Administration with Social Media: Including Applications in Student Affairs, Enrollment Management, Alumni Relations, and Career Centers, 2011: pg. 211-227. Publisher Link. This book chapter is @ Emerald Group Publishing, Ltd. and permission has been granted for this version to appear in e-Publications@Marquette. Emerald Group Publishing, Ltd. does not grant permission for this book chapter to be further copied/distributed or hosted elsewhere without the express permission from Emerald Group Publishing, Ltd. 
evolve as services and conversation channels emerge, fuse, and dissipate.

Your organization is in the center of the prism and whether you are observing, listening, or participating, a conversation about your organizations and its products are always happening and these conversations can impact and influence your business and brand. As conversations are increasingly distributed, everything begins with listening and observing. Doing so, will help you identify exactly where relevant discussions are taking place, as well as their scale and frequency. This dialog can be charted into a targeted social map that is unique to your brand (Solis, 2008).

This chapter begins with an overview of social media in higher education, who is using it and for what, then provides a few talking points to consider with others before beginning a push into social media. The remainder of the chapter includes a few examples of ways in which social media was used to engage alumni and prospective students, including a couple of projects the author worked on directly.

\section{Where Are We?}

Before beginning a discussion on any subject it is important to provide a broader context before delving into the details. Below is a look at the higher education social media environment. In July 2008 higher education Web, marketing, and communication professionals subscribed to the uweb, HighEdWeb, and SUNY CUADnet listservs were asked to complete a survey about their university's use of social media (Reuben, 2008).

The 148 unique responses from 4 different countries: the United States, Australia, Canada, and New Zealand, shed some light on the social media landscape in higher education.

- Over half (53.79\%) of the institutions reported having an official Facebook page for their campus, and 20 of them have developed a custom application for Facebook.

Higher Education Administration with Social Media: Including Applications in Student Affairs, Enrollment Management, Alumni Relations, and Career Centers, 2011: pg. 211-227. Publisher Link. This book chapter is @ Emerald Group Publishing, Ltd. and permission has been granted for this version to appear in e-Publications@Marquette. Emerald Group Publishing, Ltd. does not grant permission for this book chapter to be further copied/distributed or hosted elsewhere without the express permission from Emerald Group Publishing, Ltd. 
NOT THE PUBLISHED VERSION; this is the author's final, peer-reviewed manuscript. The published version may be accessed by following the link in the citation at the bottom of the page.

- Only $21.9 \%$ report having an official presence on MySpace, with only one responder indicating they created a custom application for MySpace.

- Nearly $67 \%$ did not have an official Twitter account for their campus, and about $64 \%$ did not have an official Flickr account.

- Just over half had an official presence on YouTube and nearly $60 \%$ had some form of blogs on their site.

- Only $17 \%$ reported using delicious, a community bookmarking website in which users can save Web pages they find and share them with other users.

The survey also asked for input on staff time for managing these social media endeavors and what the intended purposes of these activities were. Respondents reported the overwhelming majority of these tools were maintained by one or more individuals in either their marketing, communications, or public relations office.

Communication with current students and alumni was the most widely reported use and most organizations spent 1-4 h a week updating their Facebook. Those respondents that reported having an official Flickr account, nearly $43 \%$ said their marketing, communications, or public relations office maintained their presence and use was split pretty evenly between sharing photos with current students, faculty, staff, and alumni. The majority of respondents reported spending 1-4 h a week adding photos to Flickr. YouTube appeared to be used primarily for recruitment purposes $(29.50 \%)$, with some using it to share videos with current students and alumni. Most reported spending 1--4 h a week adding videos to their channel.

Despite the survey results showing an active push in higher education to utilize social media for marketing and engagement, some may still be skeptical or skittish of investing time and resources into social media.

Surveys show, however, that more and more prospective students and younger alumni are joining social networks. More than half of America's teens and young adults use social networking sites, and more than onethird of all Internet users engage in social networking (Jones \& Fox, 2009).

Higher Education Administration with Social Media: Including Applications in Student Affairs, Enrollment Management, Alumni Relations, and Career Centers, 2011: pg. 211-227. Publisher Link. This book chapter is (C) Emerald Group Publishing, Ltd. and permission has been granted for this version to appear in e-Publications@Marquette. Emerald Group Publishing, Ltd. does not grant permission for this book chapter to be further copied/distributed or hosted elsewhere without the express permission from Emerald Group Publishing, Ltd. 
Although the predominant users of social networking are young adults; three-quarters of adult Internet users under age 25 have a profile on a social networking site (Lenhart, 2009); the popularity of these sites is attracting more and more adult users. In 2005 , only $8 \%$ of adult Internet users had an online profile; today, that number has more than quadrupled to 35\% (Lenhart, 2009).

Social networking site users are also regular visitors, with more than onethird checking their profile page daily and almost another $25 \%$ visit every few days. Among teens, these numbers are higher almost half said they logged into their profile at least once a day and about one-third visit weekly. In one study of college students, males and females were equally likely to have profiles on social networking sites and were found to spend about $3 \mathrm{~h}$ each day on the sites (Raacke \& Bonds-Raacke, 2008), while two studies reported that the students limited themselves to an average of 10-30 min each day (Ellison, Steinfield, \& Lampe, 2007; Valenzuela, Park, \& Kee, 2009).

But according to the E-Expectations Class of 2007 Report, 80\% of the high school students surveyed said they had not looked for a school they were considering attending on MySpace or Facebook. Only $27 \%$ reported having read a blog written by a current student and $21 \%$ by a faculty member at a college they were considering (NoelLevitz, 2007).

Recent research is also showing that "older" users are the fastest growing group in the social media demographic. More than $50 \%$ of Facebook's members in the United States are 35 or older, and only $26.8 \%$ are 24 or under, according to an analysis of December 2009 visitors by comScore Media Metrix (Stross, 2010). Twitter is also growing rapidly among "older" users according to Nielsen, with 35-49 -year-olds making up almost $42 \%$ of the traffic to Twitter.com.

So why consider investing in social media? The social media environment contains both your prospective students and alumni, making it a great place to interface with them about your institution and programs. People are also using traditional communication sites and services (think webmail, IM, and discussion groups) less and less

Higher Education Administration with Social Media: Including Applications in Student Affairs, Enrollment Management, Alumni Relations, and Career Centers, 2011: pg. 211-227. Publisher Link. This book chapter is @ Emerald Group Publishing, Ltd. and permission has been granted for this version to appear in e-Publications@Marquette. Emerald Group Publishing, Ltd. does not grant permission for this book chapter to be further copied/distributed or hosted elsewhere without the express permission from Emerald Group Publishing, Ltd. 
and choosing to use Facebook and other social networks instead. Nielsen Online, an analytics firm that tracks time spent online at various websites, issued a report in March 2009 finding that throughout 2008 social networking sites and blogs saw more time spent by users than personal email.

Even if this data still leaves you unconvinced to make a foray into social media, then consider it the 10\% of the 70:20:10 resource allocation rule suggested by Dick Damrow: 70\% of marketing dollars should go to the programs and media that you know work; another $20 \%$ should go to new ideas to be tested; and the final $10 \%$ should be allocated to new emerging media (Sevier, 2007).

Do not underfund what already works at your institution to substantially invest in what may not, but at the same time, at least some $10 \%$ strategies will be in the $70 \%$ area in future years.

Noel-Levitz (2007) suggests that social networking can be a great resource for recruitment efforts, and could be very beneficial to your program. However, they still believe the majority of your focus should be strengthening the experience perspective students have on your official website.

Brad J. Ward (2009), who ran Butler University's admissions office social media efforts, suggests that without a solid website, you are like the homeowner who is building on sand. As a homeowner, you want to make sure your house has a solid foundation. If you build on a bad one, you might be all right in the short run but you are as good as done over time. No one wants to build on a bad foundation, and your social media efforts should be no different.

Social media provides new avenues to reach out to people, connect with them, engage in a conversation and foster a relationship. But currently a prospective student cannot apply to your school through Facebook and a donor cannot give a gift via Twitter.

The end goal is to funnel the individual to your website where they can take action, i.e. apply to your school, get more information, give a donation. Your institution can do the most creative things on

Higher Education Administration with Social Media: Including Applications in Student Affairs, Enrollment Management, Alumni Relations, and Career Centers, 2011: pg. 211-227. Publisher Link. This book chapter is (C) Emerald Group Publishing, Ltd. and permission has been granted for this version to appear in e-Publications@Marquette. Emerald Group Publishing, Ltd. does not grant permission for this book chapter to be further copied/distributed or hosted elsewhere without the express permission from Emerald Group Publishing, Ltd. 
Facebook, Twitter, or YouTube, but if the student gets to your site and cannot figure out the call to action, the action that is requested by a marketer's content (either from an advertising banner or website copy) such as how to apply or find information about a degree, you have failed. Do not let the goodwill you have built through social media be destroyed by a poorly functioning website. Before you establish why you are using social networks, examine your foundation, i.e. your institution's website.

\section{To Tweet or Not to Tweet?}

Just because you can do something does not mean you should. Although there are plenty of reasons to have a presence on Facebook, Twitter, or other social media outlets, before jumping in with both feet, take a step back, and evaluate the realm of social media at your institution and ensure you have the necessary support, both politically and staff wise to do it right.

1. Do you have the resources? Is there someone at your institution who is a social media practitioner? The kind of person who understands the world of social media networks and how to move among them like a native.

2. Do you have the experience? Although the gap is closing, there is still a big difference between surfing the web and marketing an institution. Your social media practitioner needs to not only have a working knowledge of social media outlets, but also know how to interact professionally and sell effectively. Remember, your institution's reputation is always on the line. Davenport University in Grand Rapids, Michigan recruited someone to do just this. The position is Social Media Manager, with responsibilities that include implementing, advancing, and measuring Internet communications and social media for the University.

3. Do you have the money? To do social media right, you need to invest time into developing a strategy and design, as well as ongoing updates. Time equals money, and unless you can hire your own social media practitioner like Davenport University, your staffer probably will have other responsibilities. Can you schedule them for the hours required to really manage your

Higher Education Administration with Social Media: Including Applications in Student Affairs, Enrollment Management, Alumni Relations, and Career Centers, 2011: pg. 211-227. Publisher Link. This book chapter is (C) Emerald Group Publishing, Ltd. and permission has been granted for this version to appear in e-Publications@Marquette. Emerald Group Publishing, Ltd. does not grant permission for this book chapter to be further copied/distributed or hosted elsewhere without the express permission from Emerald Group Publishing, Ltd. 
social media platforms? Expect to spend anywhere from 1 to 10 $\mathrm{h}$ a week when using social media as part of the marketing mix, depending on how many tools you use, how actively they are used by your audiences, and how extensive your presence is in each.

4. What is your central marketing team doing? This advice is for departments or schools inside a university. Check with your central marketing team to ensure that your efforts are brandcompliant and not duplicative. Your central communications office may already have a wealth of social media experience you can draw on. Even if they are not doing anything it never hurts to build cross-departmental relationships.

5. What are the compelling stories? Find the stories that humanize your institution and its constituents, i.e. students, staff, faculty, donors, etc. If possible create the story in multiple forms, written, video vignettes, and audio stories to provide different ways for visitors to access and distribute your stories.

Consider your answers to these questions before embarking on a social media campaign. There are plenty of ways to engage prospective students and alumni, in the social media realm, and the next two sections provide real world examples of ways social media were utilized to engage alumni, prospective students or both.

\section{Alumni}

It is important to reiterate that all fundraising, social media driven or not, is about building relationships and communities; stewarding your supporters and asking appropriately (both in terms of amount given and frequency of asks). This is not unique to social media or anything else.

Involved alumni are alumni who will give, and then ask how they can do more. If a college knows how to cultivate and engage its alumni, it is well on the way to financial health and growth. Although the benefits of utilizing social media are plentiful, alumni offices, with limited human and financial resources, can now reach a growing number of graduates. It still requires work, creating a Facebook page and Twitter account is just the beginning.

Higher Education Administration with Social Media: Including Applications in Student Affairs, Enrollment Management, Alumni Relations, and Career Centers, 2011: pg. 211-227. Publisher Link. This book chapter is (C) Emerald Group Publishing, Ltd. and permission has been granted for this version to appear in e-Publications@Marquette. Emerald Group Publishing, Ltd. does not grant permission for this book chapter to be further copied/distributed or hosted elsewhere without the express permission from Emerald Group Publishing, Ltd. 
Unlike a traditional fundraising job, where there is an existing community of alumni donors and friends that have a relationship with the organization, the first day you begin a social media offering, you are not part of a community nor do you have any initial followership. This is why it is important when creating your institutions' social media community to build credibility with in it and cultivate your position.

Technology, while an important component of an effective process, is not as important as the people behind it. Do not hand the task to an intern or entry-level staffer and expect it to succeed. The worst thing an institution can do is put something out there for a few months and then abandon it. You have got to make sure you have the organizational stamina to commit to doing something like this by assigning a senior-level owner to the community.

Information overload is another pitfall. Adding information to a social network is an inexpensive way to alert thousands of people about alumni events or graduates' achievements. But the messages, if they arrive too frequently, can be perceived as spam, poisoning the relationship between the college, and the graduate. Social media is particularly effective in engaging younger alumni who are not responding to traditional marketing campaigns.

Madell and Muncer (2007) while researching people aged 18-20 on why they chose to use certain communication media, especially the Internet and mobile phones for social purposes discovered participants indicated that different communication media afforded them differing levels of control over their social interactions. Research by Shao (2009) into the popularity of user-generated media (UGM) sites such as YouTube, MySpace, and Wikipedia showed that one of the reasons behind the popularity was the sense of control users have over the creation and sharing of content. Traditional marketing campaigns targeted at younger alumni may not be successful because these individuals like control over their social interactions and want the ability to engage in conversation and content creation, something the social media environment can offer.

Higher Education Administration with Social Media: Including Applications in Student Affairs, Enrollment Management, Alumni Relations, and Career Centers, 2011: pg. 211-227. Publisher Link. This book chapter is (C) Emerald Group Publishing, Ltd. and permission has been granted for this version to appear in e-Publications@Marquette. Emerald Group Publishing, Ltd. does not grant permission for this book chapter to be further copied/distributed or hosted elsewhere without the express permission from Emerald Group Publishing, Ltd. 
According to Tolliver Nigro's (2010) interview with Kate Dunn, president of a strategic marketing firm, institutions need to go where their young alumni are and that means incorporating social media into a cross-channel marketing strategy that incorporates social media, not as an afterthought, but as part of a cohesive, integrated approach. Dunn talked of working with clients that were sending the same piece to a 22-year-old as they did to a 50-year-old. Of course younger alumni were not going to respond to that. For the institutions the question became how to find these young alumni and how to engage them. In most cases they are on Facebook, so once an institution has found them, how do you go about engaging them so that they shall respond to fund-raising efforts in the future? The goal is simply to get alumni talking. It's the difference between a campaign and a conversation.

Once they are talking to you, they are more likely to give when your institution asks. Solicitations are not going to be directly through Facebook, although there will be status updates and reminders on the wall. Facebook's value is getting younger alumni re-engaged with their institution's community. Once they are re-engaged, they are more likely to give. It also makes them more aware of direct mail coming from the institution. Do not start the conversation with a tin cup out saying, "Give me money," that can cause an irreparable break in the relationship. It has to be part of an overall strategy.

In 2006 during my time as Assistant Director of Communication at University of California Irvine's Donald Bren School of Information and Computer Sciences our school wanted a way to create a more dynamic alumni chapter, one that would provide a way to connect the current students with the alumni. The current alumni chapter website was difficult to update and only a few members had access. The Associate Director of Development in conjunction with the Director of Communications suggested creating a blog, which would allow all members of the alumni chapter to create posts.

The goal for the blog was to create an open forum where students and alumni could come for a variety of reasons, i.e. students could seek advice from alumni, alumni could be profiled showing current students what career paths were available for them, and for

Higher Education Administration with Social Media: Including Applications in Student Affairs, Enrollment Management, Alumni Relations, and Career Centers, 2011: pg. 211-227. Publisher Link. This book chapter is @ Emerald Group Publishing, Ltd. and permission has been granted for this version to appear in e-Publications@Marquette. Emerald Group Publishing, Ltd. does not grant permission for this book chapter to be further copied/distributed or hosted elsewhere without the express permission from Emerald Group Publishing, Ltd. 
alumni to reflect and discuss graduate student experiences. During initial meetings with the leadership of the alumni chapter usage policies were established both on how often posts needed to be made and how user comments and interactions would be handled.

When making an entrance into the world of social media, ensure your institution first creates a written and thought out usage policy. You cannot plan for every contingency but it is better to have a sound framework to consult when an issue arises than attempting to make it up on the fly. With ground rules in place and strong support from the school's leadership, the blog was launched. Despite some slow initial growth in the amount of posts, the blog has since grown into a thriving community which has included posts on various topics such as an alumnus documenting his experience attempting to get into business school, insight into careers in consulting, and an alumnus hosting a Thanksgiving get together for fellow alumni.

Including the blog in alumni advertising and the school's other social media endeavors such as their Facebook and YouTube presence have helped sustain and grow the community.

Success with the blog inspired our school to attempt another foray into social media engagement during UC Irvine's 2009 Homecoming in which our school utilized Twitter to allow alumni in attendance to tweet their experiences so those who were not at the event could still get a sense of the experience.

Homecoming is an annual event hosted by the UC Irvine Alumni Association during a Saturday in which there is an evening men's basketball game. During the afternoon there is a street festival with games and activities and each school has a table set up where they can distribute information and as a general meeting point for alumni to reconnect with the school or meet up with fellow alumni.

Live tweeting was advertised to Bren School alumni via the alumni blog and email announcements regarding homecoming. Alums were told that if they were attending the event they could provide a first hand account of their Homecoming experience by sending updates to their Twitter account with hashtag \#brenics. Utilizing a free script

Higher Education Administration with Social Media: Including Applications in Student Affairs, Enrollment Management, Alumni Relations, and Career Centers, 2011: pg. 211-227. Publisher Link. This book chapter is (C) Emerald Group Publishing, Ltd. and permission has been granted for this version to appear in e-Publications@Marquette. Emerald Group Publishing, Ltd. does not grant permission for this book chapter to be further copied/distributed or hosted elsewhere without the express permission from Emerald Group Publishing, Ltd. 
called TwitterZoid, a page was created on the Bren School website that displayed all mentions of tweets with the hashtag \#brenics. The day of Homecoming a large graphic was placed on the Bren School homepage, that when clicked, would take visitors to a page listing all the tweets with the hashtag \#brenics.

Only a handful of alumni tweeted their experience but they did a good job capturing the events of the day and the emotion of the basketball game that ended up going down to the last basket.

Unlike an after the fact article in an alumni magazine or newsletter, the raw commentary of real alumni provided a unique personal record of Homecoming in real time for those who could not attend.

Princeton provides another example of utilizing social media to engage alumni by enhancing their experience during the annual alumni reunion. Andrew Gossen, Senior Associate Director at the Alumni Association of Princeton University, shared the experience on the Alumni Futures blog with Shaindlin (2009).

Looking for a way to reduce costs, nearly $\$ 10,000$ to print 9,500 brochures listing reunion events and activities as well as enhance the reunion experience, Princeton created a mobile friendly site called Reunions Mobile (http://m.princeton.edufreunions/).

Attendees would be able to optimize their participation, increase their ability to connect with friends and classmates on campus, and keep track of the what, where, and when of events to get the most out of their reunion experience. The site was heavily advertised through traditional marketing methods in order to reach as many alumni as possible. PAW, Princeton's alumni magazine, did a story on Reunions Mobile on their blog, the class reunion chairs were also asked to include it in their final messaging to their classmates, and put it up on their class websites.

During the Reunion event the URL was on posters at reunion headquarters, in heavy-traffic areas around campus and the link was included on the inside cover of the print brochure.

Higher Education Administration with Social Media: Including Applications in Student Affairs, Enrollment Management, Alumni Relations, and Career Centers, 2011: pg. 211-227. Publisher Link. This book chapter is @ Emerald Group Publishing, Ltd. and permission has been granted for this version to appear in e-Publications@Marquette. Emerald Group Publishing, Ltd. does not grant permission for this book chapter to be further copied/distributed or hosted elsewhere without the express permission from Emerald Group Publishing, Ltd. 
NOT THE PUBLISHED VERSION; this is the author's final, peer-reviewed manuscript. The published version may be accessed by following the link in the citation at the bottom of the page.

The reunion was held from May 28 through May 31 and according to Gossen between May 22 and May 31 there were:

- 4,170 visits to the mobile site

- 1,590 unique visitors

- 15,368 page views

For context, about 9,000 Princeton alumni (and about 20,000 total visitors) are on campus at the peak of the Reunions weekend. As for the mobile web site: $53 \%$ of visitors used the Safari browser on an iPhone, and $65 \%$ of users were on some kind of Apple handheld device. From this data Gossen drew these conclusions:

- Reunions Mobile worked well enough to serve as a primary source of information about Reunions for users of iPhones and other higher-end mobile devices.

- The team received positive feedback and constructive suggestions for future versions. Graduating seniors used the site, as did alumni at least back to the classes of the early 1970s.

Princeton spent about $\$ 7,000$ to build, test, and roll out the site and for Gossen it was well worth the time and effort. For alumni interested in this type of technology, the added value went beyond the utility of being able to access the info on their smartphones. Alumni were also really happy to see that Reunions is evolving in response to changes in the broader social and technological environment.

As smartphones garner a larger share of the market, sites like Reunions Mobile will become an increasingly realistic alternative to, or replacement for, printed brochures and schedules while allowing users to connect with other alumni and the institution. There are already free open source applications such as the Massachusetts Institute of Technology Mobile Web app which allow schools to easily create a version of their website offering up-to-date information, optimized for different types of mobile devices. Viewers can use this mobile friendly version to find people, places, events, course news, shuttle schedules,

Higher Education Administration with Social Media: Including Applications in Student Affairs, Enrollment Management, Alumni Relations, and Career Centers, 2011: pg. 211-227. Publisher Link. This book chapter is @ Emerald Group Publishing, Ltd. and permission has been granted for this version to appear in e-Publications@Marquette. Emerald Group Publishing, Ltd. does not grant permission for this book chapter to be further copied/distributed or hosted elsewhere without the express permission from Emerald Group Publishing, Ltd. 
and more. All you need is a mobile device with a web browser and either WiFi or a data plan.

\section{Prospective Students}

The Web reflects a shift to service and, more particularly, a shift to self-service. To succeed in self-service, you need a genuine understanding of, and relationship with, your customer. And you must also strive to give them a fast, simple experience.

This is just as true in the real world. According to McGovern (2010b), Starbucks is investing millions in replacing their espresso machines. These machines are in perfect working order, so why are they replacing them? They want machines that are not as high, so that the server and the customer can more easily see and interact with each other. Understanding, relating to and developing empathy for your customer (prospective student) is one of the greatest drivers of clarity in communication and social media is a way to get to truly know your customers.

A look at for-profit colleges shows the benefits of engaging and striving to know about your students. Enrollment in the country's nearly 3,000 career colleges has grown far faster than in the rest of higher education - by an average of $\%$ per year over the past 30 years, compared with only $1.5 \%$ per year for all institutions, according to an industry analyst (Zernike, 2009). For-profit universities now educate about $7 \%$ of the nation's roughly 19 million students who enroll at degree-granting institutions each fall. And the proportion rises to $10 \%$, or 2.6 million, if you count students who enroll year round (Zernike, 2009). Just this academic year, the University of Phoenix eclipsed California State University as the second largest highereducation system in the country, with 455,600 students (Zernike, 2009). Harris N. Miller, president of the Career College Association, says if the growth curve for proprietary schools continues, they could be educating more students than any other sector of higher education worldwide by 2020.

For-profit universities spend a lot of money to get students in the door. For the 3-month period ending November 30, 2009, the

Higher Education Administration with Social Media: Including Applications in Student Affairs, Enrollment Management, Alumni Relations, and Career Centers, 2011: pg. 211-227. Publisher Link. This book chapter is (C) Emerald Group Publishing, Ltd. and permission has been granted for this version to appear in e-Publications@Marquette. Emerald Group Publishing, Ltd. does not grant permission for this book chapter to be further copied/distributed or hosted elsewhere without the express permission from Emerald Group Publishing, Ltd. 
Apollo Group spent $\$ 275$-million on "selling and promotional" expenses, or about $20 \%$ of its total net (Zernike, 2009).

Although nonprofit educational institutions often do not have similar advertising budgets to get students in the door, the world of social media provides a cost effective way to engage with prospective students and build a meaningful relationship that can increase the odds of a student matriculating to the institution. The initial discussion will hover around whether to build your own social network or become part of a popular existing one such as Facebook.

Steven Infanti, director of communications and marketing at Harrisburg University of Science and Technology (Pa.), is an advocate of colleges creating their own sites. Harrisburg University's single signon web portal, Jenzabar Internet Campus Solution (JICS), was implemented in fall 2006. Infanti says the "portal better allows new students to situate themselves as part of the Harrisburg University community" (Sevier, 2007). Admitted students can access a portal just for them, and those who then choose Harrisburg University get access to an enrolled students' portal. Besides institutional information, notes Infanti, the portals offer community checklists for important dates and future plans, chat tools, and other ways to meet people. The portals take the best of social networking and limit it to the Harrisburg University community.

"We want students to connect with each other, our professors, and our administrators. This is the medium to do so. In the future, we will look at giving parents of admitted students their own portal," he said (Sevier, 2007).

However it's very difficult to gauge the effectiveness of social networks beyond running simple traffic reports. There is also the argument that since the majority of prospective students are already on Facebook and Twitter why not engage them where they are instead of trying to lure them to an institutions homegrown social network.

At the Bren School we looked at utilizing Twitter to engage prospective students even if they did not have an account on Twitter or knew what it was. I originally heard of using Twitter as a free SMS

Higher Education Administration with Social Media: Including Applications in Student Affairs, Enrollment Management, Alumni Relations, and Career Centers, 2011: pg. 211-227. Publisher Link. This book chapter is (C) Emerald Group Publishing, Ltd. and permission has been granted for this version to appear in e-Publications@Marquette. Emerald Group Publishing, Ltd. does not grant permission for this book chapter to be further copied/distributed or hosted elsewhere without the express permission from Emerald Group Publishing, Ltd. 
NOT THE PUBLISHED VERSION; this is the author's final, peer-reviewed manuscript. The published version may be accessed by following the link in the citation at the bottom of the page.

service from Brad J. Ward, who utilized it for the same purpose when he was working in the Butler University admissions office.

First, we established a Twitter account, @brenadmissions, which is where we would push updates to students. When creating a Twitter account be specific with the name and do not view it strictly as an admissions tool. An account could also be used as a way to announce athletic content scores without having to sign up with an SMS vendor.

After you get your account, you just need to tell people how to follow and then set up your page. At the Bren School we placed a call to action on our Bren:IO prospective student website and also on the web form prospective students would fill out to request additional information via mail.

Before publicizing this be sure to test it on a cell phone and walk through the process on your own.

1) Student sends a text to 40404 that says follow brenadmisions

2) If student is not on Twitter, then it will ask them to confirm their name

3) Student responds with name

4) Twitter then sets up an account for the student and gives them general Twitter advice

5) Student is notified how to opt out

6) You send your updated news from the Twitter account and it pushes straight to their cell phone.

Students do not even have to know about Twitter. To streamline the process, an institution can utilize Really Simple Syndication (RSS), a web publishing technology that allows end users to automatically receive new digital content from your institution, which can then be added to a site such as Twitterfeed.com to push updates without the need to login to Twitter and make manual updates.

From a marketing perspective this is the best option to get your content in front of a prospective student. When their phone vibrates or rings the student will instinctively look at the message and be

Higher Education Administration with Social Media: Including Applications in Student Affairs, Enrollment Management, Alumni Relations, and Career Centers, 2011: pg. 211-227. Publisher Link. This book chapter is @ Emerald Group Publishing, Ltd. and permission has been granted for this version to appear in e-Publications@Marquette. Emerald Group Publishing, Ltd. does not grant permission for this book chapter to be further copied/distributed or hosted elsewhere without the express permission from Emerald Group Publishing, Ltd. 
reminded of your school. There is no filter, no direct mail piece getting lost in the shuffle on the kitchen table, no phone call that is sent straight to voice mail or email lost in a sea of other messages. This method is a great way to remind students of upcoming admission deadlines, your school's appearance at local college fairs or announcements of interesting speakers or sporting events. You could even hold contests offering free tickets to an athletic event or a bookstore gift certificate if the first correct email response to a trivia question is received.

Remember to be up front about your privacy policy in regards to how you will handle the users data and be sure to explicitly tell users after they have signed up, how to opt out of receiving further messages if they so choose. The Mobile Marketing Association recommends it is fundamental to the concept of control that a subscriber maintains the ability to stop participating and receiving messages when desired (Mobile Marketing Association, 2010).

Flickr, the online photo sharing website, is another tool that can be used to effectively engage prospective students and sell them on the experience of attending your institution. Prospective students are looking for the truth about college life at your institution online and they are definitely bound to look for real photos taken by their peers already enrolled at your university.

Paul Stamatiou, a student at Georgia Tech as well as a popular blogger, explained in February 2005 in an exchange with one of his readers, Michael, that he did use Flickr to get a feel about the institutions he was considering:

When I was accepted into Georgia Tech, I wasn't able to visit until the summer. I had gotten into a blind agreement, but then I just hit up Flickr and was thoroughly impressed with the photos I found so I wasn't shocked or anything when I finally got a chance to visit. I also did the same thing with the other 9 or 10 colleges (yeah, I applied to a lot of schools) I was accepted into. (Joly, 2006)

Michael, apparently a student from American University, then added:

Higher Education Administration with Social Media: Including Applications in Student Affairs, Enrollment Management, Alumni Relations, and Career Centers, 2011: pg. 211-227. Publisher Link. This book chapter is (C) Emerald Group Publishing, Ltd. and permission has been granted for this version to appear in e-Publications@Marquette. Emerald Group Publishing, Ltd. does not grant permission for this book chapter to be further copied/distributed or hosted elsewhere without the express permission from Emerald Group Publishing, Ltd. 
Another thing about college+ flickr is that University Students are more likely to post and tag photos on flickr than say ... older folks. Using flickr like this is cool because you see the college campus without bias and really get a sense for what the campus is like. Plus, it's a great way to find out about the people who attend the college, which I find important. (Joly, 2006)

One way to showcase your "real" institution is to create a Flickr group and allow users to post photos to it. Amherst College, Simmons College and California State University, Chico are good examples of this concept. Amherst has a webpage in their alumni website devoted to informing visitors of the Flickr group and encouraging them to share their photos and videos with others who have an interest in the college. Each week Amherst selects a photo from the Amherst College Flickr Group to feature on the alumni homepage. The ability to comment on photos posted in the group provides an opportunity to engage prospective students with stories about the events of the photo, whether it is an athletic event or a unique campus experience.

\section{Conclusion: It Is All About Trust}

The Internet originally drew people because of the anonymity it offered (McKenna \& Bargh, 2000). Today with the maturation of social networking sites people are shedding that anonymity and are utilizing the Internet to socialize with others (Jones \& Fox, 2009).

In the social media realm where individuals have a belief that they do not want to be marketed to, how do you engage them in conversation with the intent of promoting a product or service? Successfully engaging with individuals in social networks requires building trust and relationships, providing value and becoming the goto resource when that audience is ready to buy what you sell. However the trust you build needs to be largely dependent upon your ability to convince your audience your intent is pure.

Acknowledge that your messages exist within a larger ecosystem that is beyond your control and engage consumers with this in mind. Become an active member of the community, network or environment and participate with the audience to create a genuine

Higher Education Administration with Social Media: Including Applications in Student Affairs, Enrollment Management, Alumni Relations, and Career Centers, 2011: pg. 211-227. Publisher Link. This book chapter is @ Emerald Group Publishing, Ltd. and permission has been granted for this version to appear in e-Publications@Marquette. Emerald Group Publishing, Ltd. does not grant permission for this book chapter to be further copied/distributed or hosted elsewhere without the express permission from Emerald Group Publishing, Ltd. 
NOT THE PUBLISHED VERSION; this is the author's final, peer-reviewed manuscript. The published version may be accessed by following the link in the citation at the bottom of the page.

trust. Social media is growing in influence, but if you are willing to join the conversation don't view it as a panacea, instead, first establish why you are there and adhere to that purpose.

\section{References}

Ellison, N. B., Steinfield, C., \& Lampe, C. (2007). The benefits of Facebook "friends:" Social capital and college students' use of online social network sites. Journal of Computer-Mediated Communication, 12(4), 1143-1168.

Fromm, E. (1969). Escape from freedom. New York: Avon Books.

Joly, K. (2006). Flickr, a giant real-time viewbook of college life? Available at http://collegewebeditor.com/blog/index.php/archives/2006/09/08/fiick ra-giant-real-time-viewbook-of-college-Jife/. Retrieved on April 6, 2010.

Jones, S., \& Fox, S. (2009). Generations online in 2009. Pew Internet and American Life Project. Available at http://www.pewinternet.org/Reports/2009(Generations0nlinein2009.aspx. Retrieved on April 6, 2010.

Lenhart, A. (2009). Adults and social network Web sites. Pew Internet and American Life Project. Available at http://www.pewinternet.org/Reports/2009/Adultsand-SocialNetworkWebsites.aspx. Retrieved on April 6, 2010.

Madell, D., \& Muncer, S. (2007). Control over social interactions: An important reason for young people's use of the internet and mobile phones for communication? Cyberpsychology \& Behavior, 10(1), 137140.

McGovern, G. (2010a). Customers: irrational sheep or intelligent strangers? Available at http://giraffeforum.com/wordpress/2010/04/04/ customers-irrationalsheep-or-intelligentstrangers/. Retrieved on April 30, 2010.

McGovern, G. (2010b). Web design: clarity is more important than persuasion. Available at http://giraffeforum.com/wordpress/2010/03/28/web-design-clarityismore-importantthan-persuasion/. Retrieved on April 30, 2010.

McKenna, K. Y. A., \& Bargh, J. A. (2000). Plan 9 from cyberspace: The implications of the Internet for personality and social psychology. Personality \& Social Psychology Review, 4(1), 57-75.

Mobile Marketing Association. (2010). U.S. consumer best practices guidelines for cross-carrier mobile content programs. New York: Mobile Marketing Association.

Noel-Levitz. (2007). Building an E-Recruitment network: Connecting with college bound seniors in the era ofMySpace. Available at https:/

Higher Education Administration with Social Media: Including Applications in Student Affairs, Enrollment Management, Alumni Relations, and Career Centers, 2011: pg. 211-227. Publisher Link. This book chapter is @ Emerald Group Publishing, Ltd. and permission has been granted for this version to appear in e-Publications@Marquette. Emerald Group Publishing, Ltd. does not grant permission for this book chapter to be further copied/distributed or hosted elsewhere without the express permission from Emerald Group Publishing, Ltd. 
NOT THE PUBLISHED VERSION; this is the author's final, peer-reviewed manuscript. The published version may be accessed by following the link in the citation at the bottom of the page.

jwww.noellevitz.com/NR/rdonlyres/5549FBAC-A1CE-4F27-966C2CE 16C6CFB14/0/EExpectationsClassof2007SeniorEditionpdf.pdf.

Retrieved on August 1, 2010.

Raacke, J., \& Bonds-Raacke, J. (2008). MySpace and Facebook: Applying the uses and gratifications theory to exploring friend-networking sites. Cyberpsychology \& Behavior, 11(2), 169-174.

Reuben, R. (2008). Survey about the use of social media in higher education. Available at http://doteduguru.com/id423social-media-uses-highereducation-marketing-communication.html. Retrieved on April 6, 2010. Sevier, R. (2007). Using Social Networking to Its Fullest Potential. University Business, 10(5), 25-26.

Shaindlin, A. (2009). Princeton puts reunions on your iPhone. Available at http://www.alumnifutures.com/2009/06/princeton-reunioniphone.html. Retrieved on April 6, 2010.

Shao, G. (2009). Understanding the appeal of user-generated media: A uses and gratification perspective. Internet Research, 19(1), 7-19.

Solis, B. (2008). Introducing the conversation prism. Available at http://www.briansolis.com/2008/08/introducingconversationprism.html. Retrieved on April 6, 2010.

Stross, R. (2010). Getting older without getting old. New York Times, March 7, p. 4.

Tolliver Nigro, H. (2010). Keys to success in social media marketing. Printing News, February 1, p. 11.

Valenzuela, S., Park, N., \& Kee, K. F. (2009). Is there social capital in a social network site?

Facebook use, and college students' life satisfaction, trust, and participation. Journal of Computer-Mediated Communication, 14(4), 875-901.

Veloso, M. (2009). Web copy that sells. New York: American Management Association.

Ward, B. (2009). Have you checked your foundation lately? Available at http://squaredpeg.com/index.php/2009/03/09/checked/foundation/. Retrieved on July 14, 2010.

Zernike, K. (2009). In shifting era of admissions, colleges sweat. New York Times, March 8, p. Al.

Higher Education Administration with Social Media: Including Applications in Student Affairs, Enrollment Management, Alumni Relations, and Career Centers, 2011: pg. 211-227. Publisher Link. This book chapter is @ Emerald Group Publishing, Ltd. and permission has been granted for this version to appear in e-Publications@Marquette. Emerald Group Publishing, Ltd. does not grant permission for this book chapter to be further copied/distributed or hosted elsewhere without the express permission from Emerald Group Publishing, Ltd. 
NOT THE PUBLISHED VERSION; this is the author's final, peer-reviewed manuscript. The published version may be accessed by following the link in the citation at the bottom of the page.

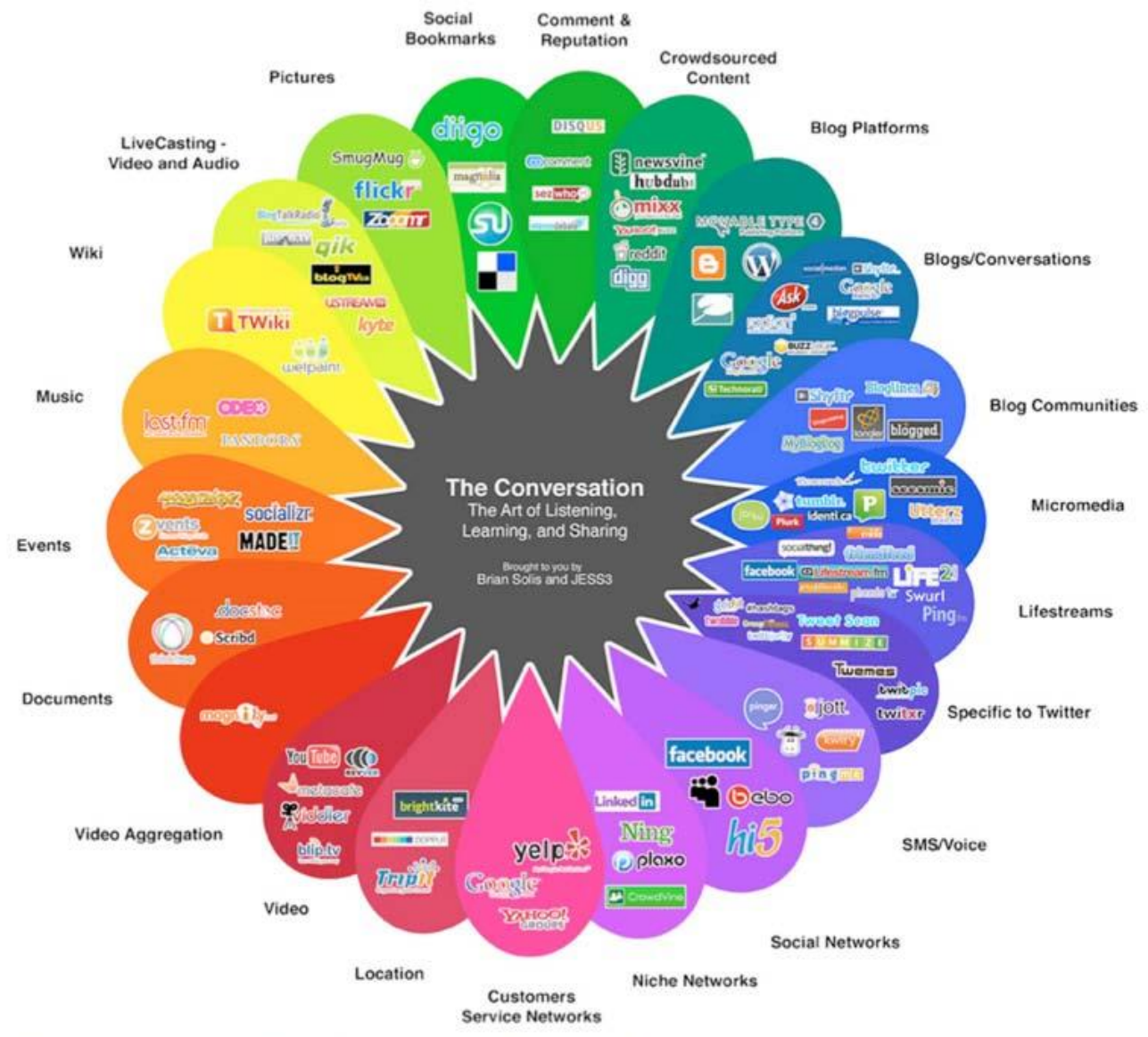

Fig. 1. Citation: "Conversation Prism." Infographic. Brian Solis. Briansolis.com. July 6, 2010.<http://www.briansolis.com>

Higher Education Administration with Social Media: Including Applications in Student Affairs, Enrollment Management, Alumni Relations, and Career Centers, 2011: pg. 211-227. Publisher Link. This book chapter is @ Emerald Group Publishing, Ltd. and permission has been granted for this version to appear in e-Publications@Marquette. Emerald Group Publishing, Ltd. does not grant permission for this book chapter to be further copied/distributed or hosted elsewhere without the express permission from Emerald Group Publishing, Ltd. 